\title{
THE DEVELOPMENT OF BRAILLE PUZZLE MEDIA FOR INCREASING THE ABILITY OF READING AND WRITING FOR CHILDREN WITH VISUAL IMPAIRMENT OF 4TH GRADE IN THE ELEMENTARY SPECIAL EDUCATION \\ PENGEMBANGAN MEDIA PUZZLE BRAILLE UNTUK MENINGKATKAN KEMAMPUAN MEMBACA DAN MENULIS ANAK TUNANETRA KELAS IV SDLB
}

\author{
Fahryzal Oktova A.S., Endro Wahyuno, Usep Kustiawan. \\ Jurusan PLB, FIP, Universitas Negeri Malang 2015, \\ E-mail: Firzal2008@gmail.com
}

\begin{abstract}
The Development of Braille Puzzle Media for Increasing The Ability of Reading and Writing for Children With Visual Impairment of 4th Grade In Elementary Special Education. The purpose of this research is developping a media that can be used to increase the reading and writing ability of child with visual impairment on fourth grade in elementary special education. This research was adapted by steps of Sugiyono's model consisting of eight steps. The result of media experts $88 \%$, matter experts $90 \%$, practicy experts $82 \%$, small group testing $82 \%$. So this product braille puzzle otherwise very worthy to be used.
\end{abstract}

Key words : Braille puzzle, reading and writing, Visual impairment

\begin{abstract}
Abstrak
Pengembangan Media Puzzle Braille Untuk Meningkatkan Kemampuan Membaca Dan Menulis Bagi Anak Tunanetra Kelas Iv Di Sdlb. Tujuan pengembangan ini adalah menghasilkan sebuah media yang dapat digunakan untuk melatih kemampuan membaca dan menulis anak tunanetra kelas IV di SDLB. Penelitian ini mengadaptasi langkahlangkah pengembangan dari Sugiyono yaitu terdiri dari 8 tahap. Hasil penilaian ahli media $88 \%$, ahli materi $90 \%$, ahli praktisi $82 \%$, dan hasil uji coba kelompok kecil 82\%. Dengan itu produk puzzle braille dinyatakan sangat layak untuk digunakan.
\end{abstract}

Kata kunci: Puzzle Braille, Membaca dan Menulis, Tunanetra

\section{PENDAHULUAN}

Tunarungu merupakan suatu istilah umum yang menunjukkan ketidakmampuan mendengar dari yang ringan sampai yang berat sekali yang digolongkan kepada tuli dan kurang dengar (Wardani, 2007). Siswa tunarungu memiliki inteligensi yang sama dengan siswa normal, namun kemampuan verbalnya mengalami hambatan sehingga mengganggu proses pembelajaran matematika yang berupa simbol dan konsep abstrak. Menurut Ashcraft dalam Katmada (2014), students with math learning difficulties exhibit high math anxiety, which is defined as "a feeling of tension, apprehension, or fear that interferes with math performance”. Jika diartikan secara bebas, siswa dengan kesulitan belajar matematika menunjukkan kecemasan matematika yang tinggi, yang didefinisikan sebagai "perasaan ketegangan, kecemasan, atau ketakutan yang mengganggu kinerja matematika". Siswa tunarungu 
yang memiliki hambatan dalam memproses konsep matematika dapat mengalami kecemasan dan ketakutan tersebut sehingga menyebabkan mereka tidak menyukai matematika. Siswa diharuskan bisa mengaitkan konsep-konsep terdahulu dengan konsep baru yang akan dipelajari dengan menggunakan alat peraga atau media sebagai bentuk manipulasi dari konsep matematika yang abstrak. Dengan begitu konsep abstrak dari matematika tersebut mudah dipahami oleh siswa.

Berdasarkan studi pendahuluan yang dilakukan peneliti pada tanggal 27 November 2014 mengenai pembelajaran matematika yang dilakukan guru dan siswa kelas III di SDLB ABCD PGRI 2 Jajag, penyajian materi masih belum sepenuhnya memperhatikan perkembangan kognitif siswa. Siswa kelas III berada pada fase operasional konkret. Hal ini berarti siswa kelas III masih membutuhkan bantuan gambar-gambar dalam memahami konsep suatu materi. Namun pada kenyataannya, materi masih disajikan langsung secara simbolik atau menggunakan media pembelajaran sederhana.

Peneliti juga melakukan wawancara kepada guru dan beberapa siswa kelas III mengenai penyajian materi menggunakan media penunjang belajar. Hasilnya, siswa tunarungu sangat aktif untuk berinteraksi dengan guru, sehingga rasa ingin tahu yang besar pada mereka harus diimbangi dengan penyajian materi atau media yang menarik dan mayoritas siswa senang dengan pembelajaran yang dilakukan sambil bermain.

Berdasarkan studi pendahuluan di atas, peneliti mencoba mengembangkan alternatif pemecahan masalah untuk materi bangun datar dengan menggunakan media permainan Ularmatika. Menurut Yulianty (2011:7), bermain merupakan suatu proses alamiah yang dengan sendirinya dilakukan oleh anak-anak. Melalui suatu permainan, diharapkan siswa dapat memperoleh kesenangan tanpa adanya paksaan. Menurut Sadiman (2002:78) permainan sebagai suatu media pembelajaran memiliki beberapa kelebihan, diantaranya permainan adalah sesuatu yang menyenangkan untuk dilakukan, sesuatu yang menghibur. Permainan memungkinkan adanya partisipasi aktif dari siswa untuk belajar. Permainan memberikan pengalaman-pengalaman nyata dan dapat membantu siswa untuk meningkatkan kemampuan kognitifnya. Beberapa manfaat belajar sambil bermain adalah menyingkirkan keseriusan yang menghambat, menghilangkan stres dalam lingkungan belajar, mengajak siswa terlibat penuh dalam pembelajaran, meningkatkan proses belajar, membangun kreativitas diri, mencapai tujuan dengan ketidaksadaran, meraih makna belajar melalui pengalaman, dan memfokuskan siswa sebagai subjek belajar (Yusuf, 2011:17). Dengan pendek kata, media permainan merupakan upaya agar siswa dapat belajar mandiri secara optimal karena siswa sebagai subjek belajar. 
Permainan dikembangkan berdasarkan kemampuan siswa tunarungu kelas III. Dengan pembelajaran menggunakan media permainan Ularmatika ini siswa diharapkan dapat mengasah kemampuan mereka dalam hal berhitung, membaca atau memahami perintah, serta mengenal bentuk benda yang ada di sekitarnya melalui permainan yang menarik. Dengan demikian, konsep pengenalan materi bangun datar melalui contoh benda konkret dapat memudahkan siswa dalam memahami materi yang abstrak.

\section{METODE}

Penelitian dan pengembangan ini mengadaptasi dari model pengembangan Sugiyono (2013:409) yang menyebutkan bahwa terdapat sepuluh langkah pengembangan, yaitu (1) Potensi masalah, (2) Pengumpulan data, (3) Desain Produk, (4) Validasi Desain, (5) Revisi Desain, (6) Uji Coba Produk, (7) Revisi Produk, (8) Uji Coba Pemakaian, (9) Revisi Produk, dan (10) Produksi Masal. Model pengembangan ini dipilih karena tahap-tahapnya sangat sistematis dan sesuai dengan karakteristik media yang akan dikembangkan.

Prosedur pengembangan media dalam penelitian dan pengembangan ini meliputi 9 langkah, yaitu (1) Potensi Masalah, (2) Pengumpulan Data, (3) Desain Produk, (4) Validasi Desain, (5) Revisi Desain, (6) Uji Coba Produk, (7) Revisi Produk, (8) Uji Coba Pemakaian, (9) Revisi Produk. Revisi produk dilakukan pada setiap akhir validasi maupun uji coba, untuk menghindari kelalaian dalam memperbaiki kekurangan media. Sehingga media yang dihasilkan benar-benar layak untuk digunakan.

Media hasil pengembangan diujicobakan melalui 3 tahap. Tahapan-tahapan tersebut meliputi (1) validasi ahli untuk mendapatkan data berupa penilaian, pendapat, dan saran terhadap isi dan tampilan media yang dikembangkan dengan subjek coba dosen ahli pendidikan matematika SD, dosen ahli media pembelajaran, dan guru SDLB B kelas III; (2) uji coba produk untuk mendapatkan data berupa penilaian dan pendapat terhadap media yang dikembangkan, serta menguji kualitas media/keterpakaian media dengan subjek coba 6 siswa kelas III SDLB PGRI 2 Jajag; (3) uji coba pemakaian untuk mendapatkan data yang lebih valid dan menilai keefektifan media dalam ruang lingkup yang lebih luas dengan subjek coba 12 siswa kelas III dan kelas IV SDLB PGRI 2 Jajag dan

\section{SDLB PGRI Genteng.}

Data yang dikumpulkan dalam penelitian dan pengembangan ini antara lain: (a) hasil penilaian dan saran validasi ahli tentang media, (b) hasil penilaian angket dan saran uji coba tentang media, dan (c) hasil belajar siswa sebelum dan setelah menggunakan media. Instrumen yang digunakan dalam penelitian dan pengembangan ini yaitu dokumen, angket, dan tes. Analisis data dilakukan 
dengan analisis deskriptif kualitatif dan analisis deskriptif kuantitatif. Penelitian dilakukan pada bulan Februari-Maret 2015.

\section{HASIL}

Pembelajaran dengan media Ularmatika coba diterapkan untuk mengatasi penyajian materi yang kurang memperhatikan perkembangan kognitif sehingga prestasi siswa kurang maksimal. Untuk mengetahui kebenaran isi dan tampilan media digunakan lembar validasi. Untuk mengetahui kelayakan media dalam pembelajaran digunakan angket penilaian media. Untuk mengetahui keefektifan media dalam meningkatkan prestasi digunakan soal tes pada sebelum dan sesudah menggunakan media.

Berdasarkan data-data yang telah dihimpun selama penelitian, menunjukkan bahwa media layak untuk digunakan dalam pembelajaran serta dapat meningkatkan prestasi. Pada setiap uji coba dilakukan pre-test, belajar menggunakan media, post-test, dan penilaian angket media.

Validasi ahli menghasilkan data hasil validasi ahli isi, data hasil validasi ahli media, dan data hasil validasi guru SDLB. Data hasil validasi ahli isi mencapai 88,75\%. Data hasil validasi ahli media mencapai 78,33\%. Data hasil validasi guru SD mencapai 90,91\%. Saran dari para validator menyatakan bahwa media sudah bagus dan layak untuk diujicobakan namun sebelumnya dilakukan revisi sesuai saran dari validator.

Setelah dilakukan revisi media dilakukan uji coba produk. Pada tahap awal dilakukan pre-test untuk mengetahui kemampuan siswa sebelum menggunakan media. Hasil pre-test mencapai persentase rata-rata 42,5\% dan hanya tidak ada siswa yang nilainya mencapai KKM. Kemudian siswa mencoba menggunakan media. Setelah menggunakan media siswa diberikan post-test untuk mengetahui kemampuan siswa sesudah menggunakan media yang hasilnya mencapai persentase ratarata $83,33 \%$. Siswa mengalami peningkatan nilai setelah menggunakan media. Kemudian guru melakukan penilaian media melalui angket yang telah disediakan. Hasil penilaian angket mencapai persentase rata-rata 92,5\% dengan komentar penilai yang menyatakan bahwa media sudah baik dan layak digunakan.

Uji coba pemakaian dilakukan setelah media direvisi sesuai hasil penailaian angket uji coba produk. Tahap yang dilakukan pada uji coba ini sama seperti pada uji coba produk. Hasil pre-test mencapai persentase rata-rata 46,67\%. Sebagian siswa sudah mampu mencapai KKM. Post-test dalam uji coba pemakaian mencapai persentase rata-rata 87,92\%. Pada uji coba ini nilai siswa mengalami peningkatan kembali bahkan lebih tinggi dari uji coba sebelumnya. Guru juga melakukan penilaian dengan angket yang hasilnya mencapai persentase rata-rata 82,5\% dengan komentar bahwa 
mereka menyukai media karena menambah kreativitas dengan soal-soal yang beragam, namun masih perlu dikembangkan dengan adanya synopsis media dan tempat bermain yang lenih luas.

\section{PEMBAHASAN}

Berdasarkan data yang diperoleh selama penelitian menunjukkan bahwa media layak digunakan dalam pembelajaran serta dapat meningkatkan prestasi siswa. Sebelum media diujicobakan, terlebih dahulu desain media divalidasi oleh 3 orang validator yang meliputi ahli isi, ahli media, dan guru SDLB. Persentase hasil validasi ahli untuk mengetahui tingkat keberhasilan media berdasarkan kriteria keberhasilan produk pengembangan yang dimodifikasi dari Arikunto (2003, 245) disajikan pada Tabel 1 berikut ini.

Tabel 1 Persentase Hasil Validasi Ahli dan Kualifikasi Keberhasilan Media

\begin{tabular}{lllll}
\hline No. & Validator & Persentase & Kualifikasi & Keterangan \\
\hline 1 & Ahli Isi & $88,75 \%$ & Sangat Valid & Tidak Revisi \\
2 & Ahli Media & $78,33 \%$ & Valid & Revisi Sedikit \\
3 & Guru SD & $90,91 \%$ & Sangat Valid & Tidak Revisi \\
\hline & Rata-rata & $\mathbf{8 5 , 9 9 \%}$ & Sangat Valid & Tidak Revisi \\
\hline
\end{tabular}

Merujuk pada Tabel 1 di atas, secara umum media yang dikembangkan memperoleh persentase rata-rata sebesar $85,99 \%$ dengan kualifikasi sangat valid yang artinya media tidak perlu direvisi. Namun pada validator ahli media masih perlu dilakukan revisi sedikit karena persentase yang diperoleh hanya sebesar 78,33\% dikarenakan masih terdapat nilai 2 pada 1 aspek. Nilai 2 diberikan pada aspek komposisi warna sajian media. Untuk menyempurnakan media maka dilakukan revisi pada aspek tersebut sehingga didapatkan media Draf I yang akan digunakan pada uji coba produk.

Sebelum melakukan tahap uji coba produk, siswa terlebih dahulu mengerjakan soal pre-test namun hasil ketuntasan yang diperoleh masih belum maksimal. Ketuntasan pada uji coba produk mencapai 0\%. Untuk subjek uji coba produk yang tergolong kemampuan sedang sampai rendah, ternyata masih mengalami kesulitan memahami perintah soal. Hal ini bukan hanya dipengaruhi dari kemampuan subjek uji coba, tetapi dikarenakan subjek uji coba sama sekali belum pernah menggunakan model pre-test dalam pembelajaran. Oleh karena itu demi mencapai ketuntasan tes sebagai wujud ketuntasan penguasaan materi peneliti melakukan bantuan pemahaman terhadap perintah soal tes agar siswa dapat menjawab sesuai perintah yang diberikan. Selain itu, siswa juga belum memahami tentang bentuk-bentuk bangun datar, sehingga mereka lebih memerlukan pembelajaran yang kontekstual. Setelah melakukan uji coba media Ularmatika, siswa diberi post-test untuk menguji kembali pemahaman siswa tentang materi bangun datar. Hasil ketuntasan mencapai 100\%. Dengan demikian, dapat disimpulkan siswa mengalami kenaikan hasil belajar sebesar 40,83\%. 
Hal ini menunjukkan bahwa media Ularmatika menarik dan dapat membantu siswa dalam belajar materi bangun datar pada uji produk.

Selanjutnya, media Ularmatika digunakan untuk uji coba pemakaian. Sebelum melakukan tahap uji coba pemakaian, siswa terlebih dahulu mengerjakan soal pre-test namun hasil ketuntasan yang diperoleh masih belum maksimal. Ketuntasan pada uji coba pemakaian mencapai 25\%. Subjek uji coba yang mendapat skor dibawah KKM 70 merupakan siswa dengan kemampuan sedang sampai rendah. Untuk subjek uji coba pemakaian yang belum memenuhi KKM 70, ternyata masih mengalami kesulitan membedakan bentuk bangun datar segiempat dan segitiga serta dalam memahami contoh benda dari bangun datar tersebut. Oleh karena itu demi mencapai ketuntasan siswa dalam memahami materi bangun datar, siswa diajak untuk melakukan pembelajaran yang kontekstual dengan media Ularmatika. Setelah melakukan uji coba media Ularmatika, siswa diberi post-test untuk menguji kembali pemahaman siswa tentang materi bangun datar. Hasil ketuntasan mencapai $100 \%$. Dengan demikian, dapat disimpulkan siswa mengalami kenaikan hasil belajar sebesar 41,25\%. Hal ini menunjukkan bahwa media Ularmatika menarik dan dapat membantu siswa dalam belajar materi bangun datar pada uji coba pemakaian.

Untuk menilai keefektifan, keefisienan, dan kemenarikan media, dalam uji coba produk maupun uji coba pemakaian dilakukan penilaian melalui angket. Persentase hasil penilaian angket untuk mengetahui tingkat keberhasilan media berdasarkan Tabel Kriteria Keberhasilan Produk Pengembangan yang dimodifikasi dari Arikunto (2003:245) disajikan pada Tabel 2 berikut ini.

\begin{tabular}{|c|c|c|c|c|}
\hline No. & Uji Coba & Persentase & Kualifikasi & Keterangan \\
\hline 1 & Produk & $92,5 \%$ & Sangat Valid & Tidak Revisi \\
\hline \multirow[t]{2}{*}{2} & Pemakaian & $82,5 \%$ & Sangat Valid & Tidak Revisi \\
\hline & Rata-rata & $87,5 \%$ & Sangat Valid & Tidak Revisi \\
\hline
\end{tabular}

Berdasarkan Tabel 2 di atas, secara umum media hasil pengembangan memperoleh persentase rata-rata sebesar $87,5 \%$ dengan kualifikasi sangat valid sehingga media tidak perlu revisi dan layak untuk digunakan dalam pembelajaran pada siswa kelas III semester 2. Hal ini didukung dengan paparan kelayakan penilaian angket oleh masing-masing subjek uji coba yang disajikan pada Tabel 3 berikut ini.

Tabel 3 Persentase Hasil Penilaian Angket Uji Coba

\begin{tabular}{llll}
\hline No. & Subjek Uji Coba & Persentase & Kualifikasi \\
\hline 1 & $\mathrm{~K}$ & $92,5 \%$ & Sangat Layak \\
2 & $\mathrm{~L}_{1}$ & $78,3 \%$ & Layak \\
3 & $\mathrm{~L}_{2}$ & $86,67 \%$ & Sangat Layak \\
\hline
\end{tabular}


Keterangan:

$\mathrm{K} \quad$ : penilai uji coba produk

$\mathrm{L}_{1}-\mathrm{L}_{2}$ : penilai uji coba pemakaian

Merujuk pada Tabel 3 di atas, menunjukkan bahwa media yang dikembangkan dapat digunakan oleh subjek uji coba dengan baik. Terbukti bahwa 66,67\% penilai uji coba menilai media yang dikembangkan sangat layak untuk digunakan dan sisanya sebesar 33,33\% menilai media yang dikembangkan layak untuk digunakan. Media pembelajaran yang dikembangkan juga dinilai dapat meningkatkan prestasi siswa apabila dilihat dari hasil pre-test dan post-test pada tiap-tiap uji coba. Persentase hasil pre-test dan post-test untuk mengetahui tingkat ketercapaian hasil belajar berdasarkan Tabel Kriteria Ketercapaian Hasil Belajar yang dimodifikasi dari Arif Z. (2012:236) disajikan pada Tabel 4 berikut ini.

Tabel 4 Persentase Hasil Pre-test dan Post-test serta Tingkat Penguasaan Subjek Uji Coba

\begin{tabular}{llllll}
\hline \multirow{2}{*}{ No. Uji Coba } & Pre Test & \multicolumn{3}{c}{ Post Test } \\
\cline { 3 - 6 } & Persentase & $\begin{array}{l}\text { Tingkat } \\
\text { Penguasaan }\end{array}$ & Persentase & $\begin{array}{l}\text { Tingkat } \\
\text { Penguasaan }\end{array}$ \\
\hline 1 & Produk & $42,5 \%$ & Kurang & $83,33 \%$ & Baik \\
2 & Pemakaian & $46,67 \%$ & Kurang & $87,92 \%$ & Baik \\
\hline & Rata-rata & $\mathbf{4 4 , 5 8 \%}$ & Kurang & $\mathbf{8 5 , 6 2 \%}$ & Baik \\
\hline
\end{tabular}

Melihat dari Tabel 4 di atas, menunjukkan bahwa persentase rata-rata hasil belajar pada tiaptiap uji coba terjadi peningkatan. Secara umum, pada pre-test persentase rata-ratanya hanya mencapai 44,58\% dengan tingkat penguasaan kurang, sedangkan pada post-test mengalami peningkatan menjadi $85,62 \%$ dengan tingkat penguasaan baik. Media juga dinyatakan layak digunakan karena persentase siswa subjek uji coba memenuhi syarat minimal $70 \%$ dari siswa yang hasil belajarnya (post-test) mencapai KKM dengan rincian yaitu pada uji coba produk keseluruhan siswa dari 6 siswa atau sebesar $100 \%$ mampu mencapai KKM dan pada uji coba pemakaian seluruh siswa subjek uji coba sebanyak 12 siswa atau sebesar 100\% mampu mencapai KKM. Hasil belajar siswa dapat mengalami peningkatan karena siswa sebagai subjek belajar terlibat penuh dalam permainan yang menyenangkan sehingga materi pembelajaran dapat dimengerti dengan baik. Hal ini sesuai dengan manfaat belajar sambil bermain dari pendapat Yusuf (2011) yaitu menyingkirkan keseriusan yang menghambat, menghilangkan stres dalam lingkungan belajar, mengajak siswa terlibat penuh dalam pembelajaran, meningkatkan proses belajar, membangun kreativitas diri, mencapai tujuan dengan ketidaksadaran, meraih makna belajar melalui pengalaman, dan memfokuskan siswa sebagai subjek belajar.

Setelah melakukan serangkaian uji coba, didapatkan hasil bahwa untuk pembelajaran menggunakan media Ularmatika pada siswa kelas III SDLB tidak sepenuhnya siswa bisa dibiarkan bermain secara mandiri. Terutama bagi siswa yang terbiasa dengan pembelajaran konvensional 
dimana guru menjadi pusat dalam pembelajaran. Oleh karena itu, guru harus benar-benar bertindak sebagai fasilitator. Dari segi media, yang menjadi kekurangan yaitu penggunaan sebaiknya dilakukan dengan komunikasi total agar siswa dapat memahami kalimat soal, terutama siswa dengan kemampuan sedang sampai rendah. Hal ini dimaksudkan agar tidak menghabiskan banyak waktu permainan karena siswa harus memahami kalimat soal dengan membaca berulang-ulang.

\section{KESIMPULAN DAN SARAN}

Media sebagai produk pengembangan dikaji mengenai sinopsis media, wujud media, kelebihan produk, dan kelemahan produk. Sinopsis media berupa identitas pengembang dan identitas produk, yaitu nama media, alat dan bahan, cara pembuatan, Standar Kompetensi, Kompetensi Dasar, indikator, tujuan pembelajaran, materi pembelajaran, karakteristik sasaran, prosedur pemanfaatan, dan evaluasi. Wujud produk berupa media permainan terdiri dari papan permainan, dadu, kartu permainan, bidak pemain, bendera, styrofoam dan reward.

Kelebihan produk yaitu media dilengkapi dengan petunjuk/sinopsis untuk guru, materi disajikan dengan memperhatikan perkembangan kognitif siswa, siswa dapat belajar tentang konsep matematika yang bersifat abstrak (berupa simbol, lambang, dll) dengan lebih mudah melalui benda konkret di lingkungan kelas atau sekolah sebagai contoh, warna yang menarik perhatian siswa karena siswa tunarungu lebih fokus pada pembelajaran visual, aturan main yang sederhana sehingga dapat diikuti siswa, terdapat kartu reward sebagai hadiah tambahan bagi siswa, memupuk moral siswa dalam sikap antri menunggu giliran bermain dan memberikan kesempatan untuk pelajaran remedial, yakni memperbaiki kesalahan, kelemahan atau kekurangan yang ditemukan siswa sendiri berdasarkan soal yang diberikan. Kelemahan produk yaitu guru memiliki persiapan lebih dalam menjelaskan media permainan ini kepada siswa tunarungu dengan kalimat yang mudah dimengerti, siswa dimungkinkan mengalami kesulitan dalam membaca atau memahami perintah pada kartu bangun datar sehingga guru harus membantu dengan isyarat, dan siswa salah menghitung dalam menjalankan bidak pemain sesuai jumlah titik pada dadu sehingga dapat terjadi kesalahan penempatan posisi.

Hasil penelitian dan pengembangan ini memiliki saran-saran yang dikelompokkan menjadi tiga, yaitu: (1) saran pemanfaatan, (2) saran diseminasi, dan (3) saran pengembangan produk lebih lanjut. Saran pemanfaatan, yaitu media pembelajaran ini sebaiknya tidak dijadikan satu-satunya media dan sumber belajar dalam pembelajaran matematika di kelas III SDLB. Pada akhir permainan, hendaknya siswa diberi kesempatan untuk berkonsultasi mengenai hal-hal yang belum bisa dipahami siswa secara mandiri sebagaimana peran guru sebagai fasilitator. Saran diseminasi, yaitu media 
didiseminasikan ke tingkat kecamatan bahkan sampai ke tingkat kabupaten, sehingga media lebih fleksibel untuk digunakan pada kalangan yang lebih luas. Saran pengembangan produk lebih lanjut, yaitu produk pengembangan ini sebaiknya dikembangkan lebih lanjut dengan materi-materi dari kompetensi dasar lain atau bahkan materi-materi matematika lain yang ada di kelas III yang sesuai. Guru-guru juga dapat mengembangkan media untuk semua materi matematika sesuai dengan kelas yang diajarnya. Penggunaan kalimat petunjuk maupun perintah dalam media sebaiknya disesuaikan dengan tingkat kemampuan siswa, karena media dalam penelitian dan pengembangan ini berfungsi sebagai media sekaligus sumber belajar yang langsung digunakan oleh siswa dan guru hanya bertindak sebagai fasilitator. Perlu sekiranya dilakukan penelitian terlebih dahulu mengenai kemampauan berbahasa siswa kelas III SDLB tunarungu, sehingga hasil penelitian tersebut dapat menjadi pijakan pengembang untuk mengembangkan kalimat dalam media supaya dapat digunakan oleh siswa dengan kemampuan tinggi sampai rendah.

\section{DAFTAR RUJUKAN}

Arikunto, Suharsimi. 2003. Dasar-Dasar Evaluasi Pendidikan. Jakarta: Bumi Aksara.

Katmada, A. dkk. 2014. Implementing a Game for Supporting Learning in Mathematics. Electronic Journal of e-Learning, $12 \quad$ (3), (Online), (https://www.google.co.id/url?sa=t\&rct=j\&q=\&esrc=s\&source=web\&cd=1\&cad=rja\&uact= 8\&ved=0CBsQFjAA\&url=http\%3A\%2F\%2Fwww.ejel.org\%2Fissue\%2Fdownload.html\%3 FidArticle\%3D284\&ei=v-

YzVenmGojnuQTKrIDwCA\&usg=AFQjCNHXT1FrrbC9eSkVsxBM1F2rMdzuBQ\&bvm=b v.91071109,d.c2E), diakses 12 Januari 2015.

Sadiman, Arief, Rahardjo, R., Haryono, Anung \& Rahardjito. 2002. Media

Pendidikan, Pengertian Pengembangan dan Pemanfaatannya. Jakarta:

Pustekkom Dikbud dan PT Raja Grafindo Persada.

Sugiyono. 2013. Metode Penelitian Pendidikan. Bandung: Alfabeta.

Wardani, I.G.A.K., Hernawati, T., dan Astati. 2007. Pengantar Pendidikan Luar Biasa. Jakarta: Universitas Terbuka.

Yulianty, Rani. 2011. Permainan yang Meningkatkan kecerdasan Anak Modern dan Tradisional. Jakarta: Laskar Aksara.

Yusuf, Yasin \& Auliya, Umi. 2011. Sirkuit Pintar Melejitkan Kemampuan Matematika \& Bahasa Inggris dengan Metode Ular Tangga. Jakarta: Visimedia.

Z., Arif. 2012. Evaluasi Pembelajaran. Bandung: PT. Remaja Rosdakarya. 